\title{
نصوص المال الحرام في القرآن الكريم: مقاربة دلالية بيانية
}

Mahmud KADDUM1

Abdellah ALAMі²

APA: Kaddum, M.; Alami, A. (2021). نصوص المال الحرام في القرآن الكريم: مقاربة دلالية بيانية RumeliDE Dil ve Edebiyat Araşttrmaları Dergisi, (25), 814-830. DOI: 10.29000/rumelide.1036603.

الملخص

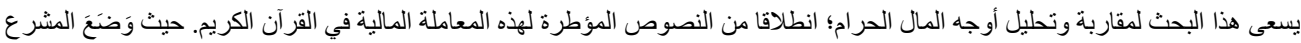

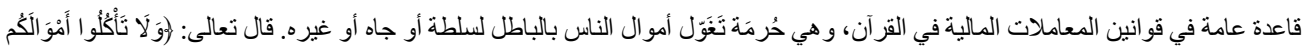

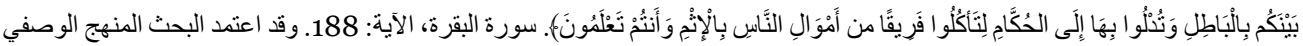

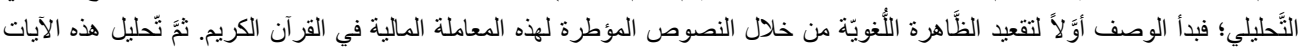

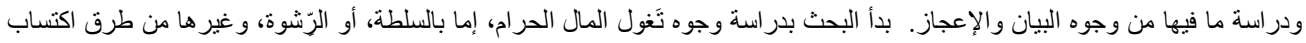

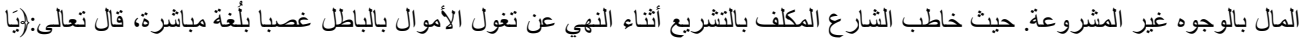

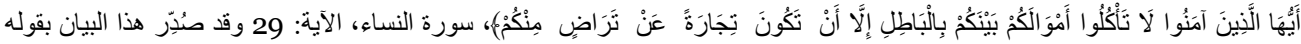

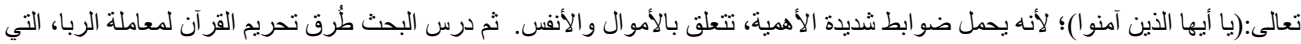

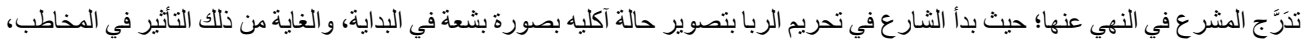

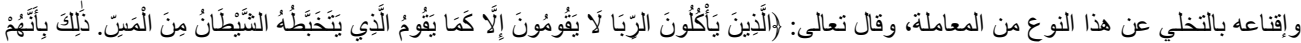

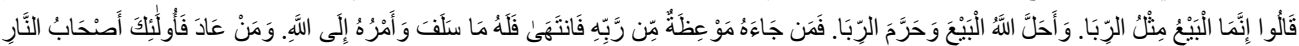

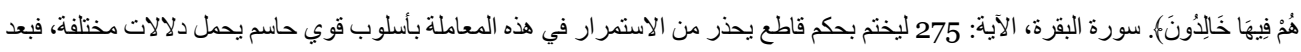

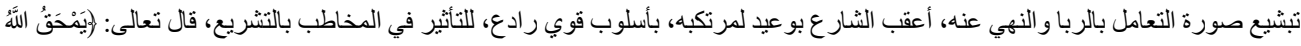

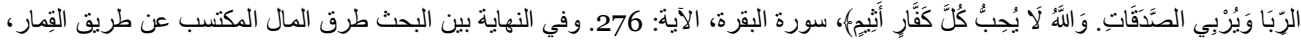

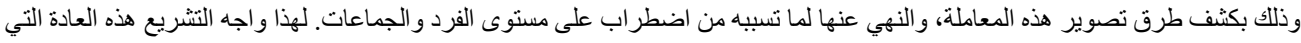

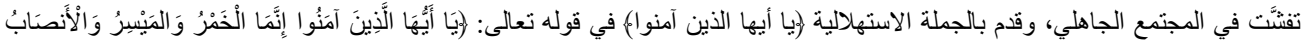

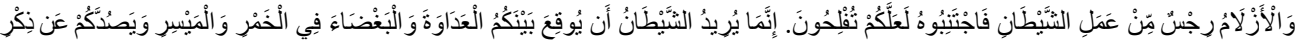

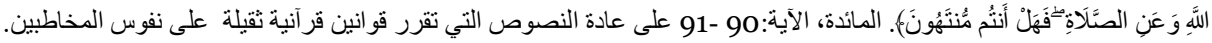

الكلمات المفتاحية: اللغة العربية وبلاغتها، المال الحرام، الدلالة، البيان، التحليل.

\section{9-Kuran-1 Kerim'deki haram paraya dair naslar: Delalete ve anlama dayalı yaklaşım}

\section{$\ddot{O} \mathbf{z}$}

Bu araştırma, Kur'an-ı Kerim'de haram malın işlemi ile ilgili mevcut nasların çerçevesine dayanarak haram paranın yönlerine dair bir yaklaşımda bulunmayı ve bu yönleri analiz etmeyi amaçlamaktadır. Nitekim şâri olan Allah, Kur'an-ı Kerim'de mali muamelelerle ilgili kurallar koymuştur. Bu da insanların mallarının şan, güç ve benzeri bir şeyin elde edilmesi amacıyla batıl yollarla yok edilmesinin haram kılınmasıdır. Allah Teâlâ şöyle buyurmuştur: "Mallarınızı aranızda haksızlıkla yemeyin. Bile bile, günaha saparak, insanların mallarından bir kısmını yemeniz için onun bir parçasını yetkililere aktarmayın.” (Bakara: 188). Araştırma analitik ve niteleyici yöntemi

Doç. Dr., Bartın Üniversitesi, Edebiyat Fakültesi, Mütercim ve Tercümanlık (Arapça) ABD Başkanı (Bartın, Türkiye), mkaddum@bartin.edu.tr, ORCID ID: 00oo-0002-9636-4903 [Araştırma makalesi, Makale kayıt tarihi: 05.10.2021-kabul tarihi: 20.12.2021; DOI: 10.29000/rumelide.1036603]

Dr. Öğr. Üyesi, University of Minnesota, College of Communication Science, Department of Discourse Analysis, (Minnesota, USA) alami541@hotmail.com, ORCID ID: oooo-0002-6625-1625 
benimsemiştir. İlk olarak Kuran-ı Kerim'deki mal ile ilgili ayetler aracılığyla dil olgusunu sağlam temellere oturtmakla başlamıs, ardından bu ayetleri analiz edip içlerindeki beyan ve i‘câz yönlerini incelemiştir. Araştırma, güç kullanma, rüşvet veya diğger yasa dışı yollarla haram elde etme şekillerini incelemekle başlamıştır. Yüce Allah şöyle buyurmuştur: "Ey iman edenler! Mallarınızı aranızda haksızlıkla yemeyin; ancak karşılıklı rızânıza dayanan ticaret böyle değildir.” (Nisa: 29) Mal ve nefislere dair çok önemli kurallar taşıdığı için ayette hitaba "Ey iman edenler" sözüyle başlanmıştır. Araştırma daha sonra, Kuran'ın faiz işlemini aşama aşama yasaklama yollarını incelemiştir. Şöyle ki, Allah Teâlâ ilk olarak faiz yiyen kimsenin çirkin durumunu açıklayarak onu yasaklamaya başlamıştır. Bunun amacı muhatabı etkilemek ve onu bu tür muameleleri bırakmaya ikna etmektir. Allah Teâlâ şöyle buyurmuştur: "Faiz yiyenler ancak şeytanın çarparak sersemlettiği kimse gibi kalkarlar. Bunun sebebi onların, 'Alım satım da ancak faiz gibidir' demeleridir. Hâlbuki Allah alım satımı helal, faizi ise haram kılmıştır. Artık kime Allah’tan bir öğüt erişir de faizciliği bırakırsa geçmişteki kendisinindir; durumunun takdiri ise Allah'a aittir. Kim de yine faizciliğe dönerse işte bunlar devaml kalmak üzere cehennemliklerdir.” ( Bakara: 275 ). Allah Teâlâ, bu işlemi sürdürmeye karşı çeşitli delaletleriyle birlikte kuvvetli ve kesin bir uyarı içeren bir hükümle ayeti sona erdirmek amacıyla faiz muamelesini çirkin gösterip onu yasakladıktan sonra teşri ile muhatabı etkilemek için faiz muamelesinde bulunanlara yönelik güçlï ve caydırıcı bir tehdidi akabinde getirmiştir: "Allah faizi yok eder, sadakaları ise arttırır ve Allah hiçbir inkârcı günahkârı sevmez.” ( Bakara: 276 ). Araştırma son bölümde, kumar oynayarak kazanılan para yollarından bahsetmiştir. Bunu da söz konusu işlemi betimleme yollarını ortaya çıkararak yapmıştır. Yine araştırma faizin birey ve toplum seviyesinde neden olduğu düzensizlik nedeniyle yasaklanmasını ele almıştır. Bu yüzden şeriat, İslâm öncesi toplumda yayılan bu geleneğe karşı çıkmış ve muhatapların nefislerine ağır gelen Kur'an kanunlarını ifade eden naslarda olduğu üzere istihlâliye (başlangıç) cümlesi olan 'Ey iman edenler!' ifadesiyle hitaba başlayarak şöyle buyurmuştur: "Ey iman edenler! İçki, kumar, dikili taşlar, fal okları şeytan işi iğrenç şeylerden ibarettir. Bunlardan kaçının ki kurtuluşa eresiniz. Şüphesiz şeytan içki ve kumar yoluyla aranıza düşmanlık ve kin sokmak, sizi Allah'ı anmaktan ve namazdan alıkoymak ister. Artık vazgeçtiniz değil mi?” (Maide: 90,91).

Anahtar kelimeler: Arap dili ve belagati, haram para, delâlet, beyân, tahlil

\title{
Texts of forbidden money in the Holy Qur'an: Graphic semantic approach
}

\begin{abstract}
There is no doubt that the Qur'anic structure is the biggest factor in increasing the richness of the meanings of the vocabulary that it forms, and this is due to the truth of the linguistic structure itself, since the composition is the most prominent determinant of the significance that is not matched by that lexical or rhetorical factor, if the singular word in the dictionary has one approximate connotation It has many potential connotations. If it enters into the composition, the context and the adjacent terms give it a unique and accurate lexical connotation. This research seeks to approach and analyze aspects of unlawful money. Based on the texts framed for this financial transaction in the Holy Quran. Whereas, the legislator has set a general rule in the laws of financial transactions in the Qur'an, which is the prohibition on falsehood that invalidates the wealth of people for authority or others. Allah says : "And do not eat up your property among yourselves for vanities, nor use it as bait for the judges, with intent that ye may eat up wrongfully and knowingly a little of (other) people's property " (Surah Al-Baqarah, Verse: 188). The research adopted the analytical descriptive method. The description first began to complicate the linguistic phenomenon through the texts framed for this
\end{abstract}


financial transaction in the Holy Qur'an. Then analyze these verses and study their manifestations and miracles. The research began by studying the faces of illegitimate money gaining ground, either through power, or bribery, and other methods of acquiring money through unlawful faces. Where the Legally component addressed with legislation during the prohibition of the invalidation of wealth by force, directly, the Almighty says:"O ye who believe! Eat not up your property among yourselves in vanities: But let there be amongst you Traffic and trade by mutual good-will: Nor kill (or destroy) yourselves: for verily Allah hath been to you Most Merciful" . Surah An-Nisa, verse: 29, Almighty: (O you who believe); Because it carries very important controls related to money and souls. Then the research examined the methods of the Qur'an forbidding the treatment of usury, which the legislator gradually prohibited. Where the lawmaker began to prohibit usury by portraying the situation of those who eat it ugly at the beginning, and the aim of that was to influence the addressee, and to persuade him to abandon this kind of treatment. The reason is that they said that selling is like interest. And God permitted sales and forbidden usury. So whoever sends an exhortation from his Lord and finishes it, he will have the foregoing and his command is to God. And whoever returns, those who are the companions of the fire are in it they will be immortal. (Surat Al-Baqarah, Verse: 275) to conclude with a categorical ruling that warns against continuing this transaction in a strong and decisive manner that carries various connotations. Allah will deprive usury of all blessing, but will give increase for deeds of charity: For He loveth not creatures ungrateful and wicked ((Surat AlBaqarah, verse: 276). In the end, the research showed the methods of money earned through gambling, by revealing ways to portray this transaction, and forbidding it because of the disturbance it causes on the individual and group levels. This legislation faced the habit that prevailed in the preIslamic society and gave the introductory wholesale O you who Amnoa( in the verse: O you who believe, but wine, and gambling and an abomination of Satan, avoid that ye may prosper. Only Satan wants to cause enmity and hatred in wine and indulgence to cause enmity and resentment among you, and to block you from the remembrance of God. (Al-Ma'idah, verse: 90-91) is based on the custom of texts that establish heavy Quranic.

Keywords: Arabic language and rhetoric, unlawful money, connotation, statement, analysis

\section{Summary}

This research seeks to approach and analyze aspects of unlawful money. Based on the texts framed for this financial transaction in the Holy Quran. Whereas, the legislator has set a general rule in the laws of financial transactions in the Qur'an, which is the prohibition on falsehood that invalidates the wealth of people for authority or others. Allah says : "And do not eat up your property among yourselves for vanities, nor use it as bait for the judges, with intent that ye may eat up wrongfully and knowingly a little of (other) people's property ". (Surah Al-Baqarah, Verse: 188)

The research adopted the analytical descriptive method. The description first began to complicate the linguistic phenomenon through the texts framed for this financial transaction in the Holy Qur'an. Then analyze these verses and study their manifestations and miracles.

The research began by studying the faces of illegitimate money gaining ground, either through power, or bribery, and other methods of acquiring money through unlawful faces. Where the Legally component addressed with legislation during the prohibition of the invalidation of wealth by force, directly, the Almighty says:"O ye who believe! Eat not up your property among yourselves in vanities: But let there be amongst you Traffic and trade by mutual good-will: Nor kill (or destroy) yourselves: for verily Allah 
hath been to you Most Merciful". Surah An-Nisa, verse: 29, Almighty: (O you who believe); Because it carries very important controls related to money and souls.

Then the research examined the methods of the Qur'an forbidding the treatment of usury, which the legislator gradually prohibited. Where the lawmaker began to prohibit usury by portraying the situation of those who eat it ugly at the beginning, and the aim of that was to influence the addressee, and to persuade him to abandon this kind of treatment. The reason is that they said that selling is like interest. And God permitted sales and forbidden usury. So whoever sends an exhortation from his Lord and finishes it, he will have the foregoing and his command is to God. And whoever returns, those who are the companions of the fire are in it they will be immortal. (Surat Al-Baqarah, Verse: 275) to conclude with a categorical ruling that warns against continuing this transaction in a strong and decisive manner that carries various connotations. Allah will deprive usury of all blessing, but will give increase for deeds of charity: For He loveth not creatures ungrateful and wicked ((Surat Al-Baqarah, verse: 276).

In the end, the research showed the methods of money earned through gambling, by revealing ways to portray this transaction, and forbidding it because of the disturbance it causes on the individual and group levels. This legislation faced the habit that prevailed in the pre-Islamic society and gave the introductory wholesale $\mathrm{O}$ you who Amnoa( in the verse: $\mathrm{O}$ you who believe, but wine, and gambling and an abomination of Satan, avoid that ye may prosper. Only Satan wants to cause enmity and hatred in wine and indulgence to cause enmity and resentment among you, and to block you from the remembrance of God. (Al-Ma'idah, verse: 90-91) is based on the custom of texts that establish heavy Quranic laws on the souls of addressees.

The beginning of this research was the study and analysis of the texts of the provisions on money, and it is an attempt to analyze these texts semantically and graphically, to come out in the end with a set of results and conclusions.

This research proceeded according to a plan that analyzed texts related to money flow in general, then studied the texts forbidden for usurious transactions, to conclude the article by deconstructing the texts forbidden for gambling.

We came out of our semantic and analytical study of the texts of forbidden money in the Qur'an with a number of results:

- The legislator has set a general rule in acquiring money, which is clarity and combating fraud and deception, and the injustice of the strong and the weak; Because it is a person's habit to exploit the strong and weak, especially with regard to the aspect of financial transactions.

- The Qur'an also established its financial system on a solid foundation, so it forbids usurious transactions. In order for money not to be a state among the rich, the legislator has laid down a general rule in the laws of financial transactions in the Qur'an, which is the prohibition on the wealth of people being invaded by wrongful authority, authority or others. And that is what God Almighty says: "And do not eat up your property among yourselves for vanities, nor use it as bait for the judges, with intent that ye may eat up wrongfully and knowingly a little of (other) people's property." (Surat Al-Baqarah, Verse: 188). 
In order to convey these meanings, the legislator begged with methods of clarification. To photograph forbidden financial transactions, and to report his own system. He also established its texts according to an accurate semantic structure that serves major purposes. For money system in the Holy Quran.

مقدّمة

كان مبتدأ هذا البحث دراسة وتحليل نصوص الأحكام الخاصة بالأموال، وهي محاولة لتحليل هذه النصوص دلاليا وبيانيا، لنخرج في النهاية بجملة من النتائج و الخلاصنات.

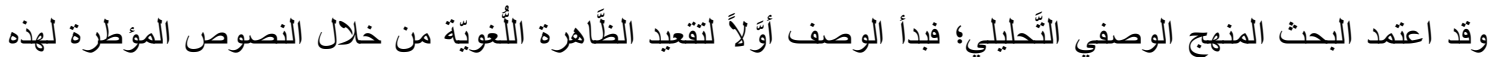

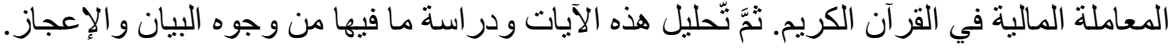

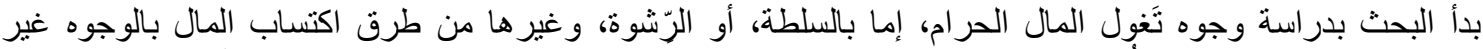

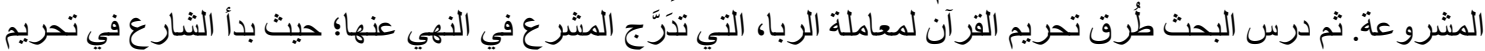

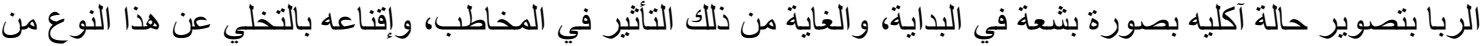

المعاملة الربالة

وفي النهاية بين البحث طرق المال المكتسب عن طريق القِمار، وذللك بكثف طرق تصوير هذه المعاملة، و النهي عنها لما تسببه من اضطر اب على مستوى الفرد و الجماعات. لهذا واجه التشريع هذه العادة التي تفثنَّت في المجتمع الجاهلي.

وقد اطلعنا على جملة من الدراسات التي تتقاطع مع موضوع البحث، فلم نجد بحثا اهتم بالجانب اللغوي الدلالي المكتنه

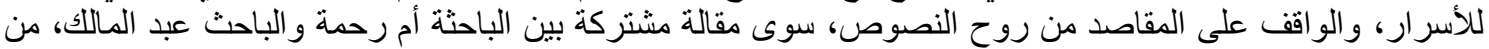

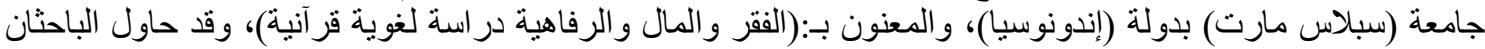

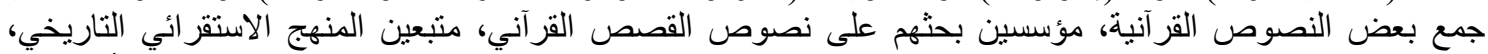

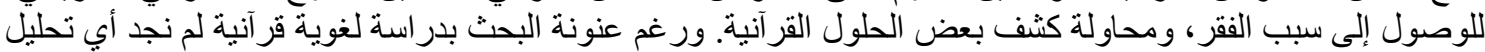

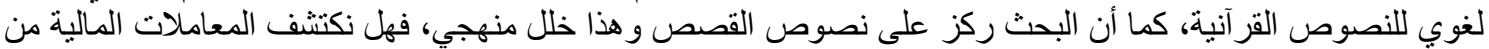
نصوص القصص أم من نصوص آنة كمان الأحكام؟!

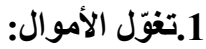

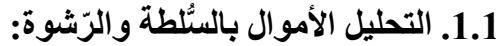

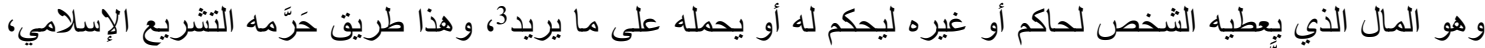

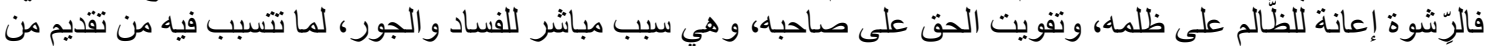

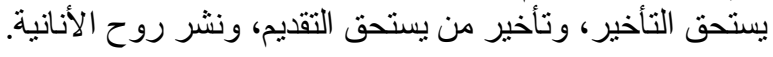

و لا يدخل في الرّّشوة دفع المال لتحصيل حق، أو دفع الأذى والضرر، إذ يجوز للمسلم أن يدفع ماله رشوة تحصيلا لحقه، ودفعا للضرر و الأذى عن نفسة فئ.

وفي هذه الحالة يقع الإثم على المرتثي وحده، يقول ابن حزم الأندلسي ـقدس الله سره-: "و أما الآخذ فآثم، وفي كلا الوجهين

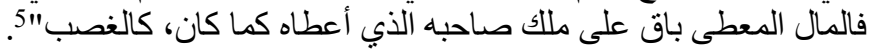

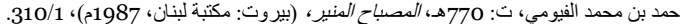

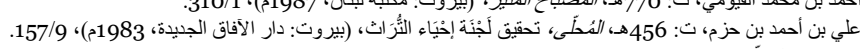

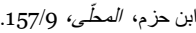




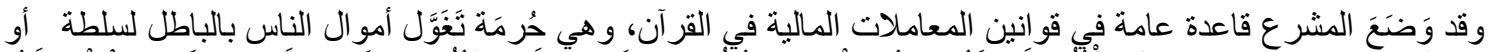

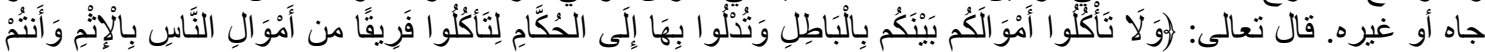

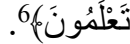

فالتعبير بقوله: (لا تأكلوا) استعارة، دلالتها تنفير المخاطب من هذا الفعل الثنَّنع. والأكل حقيقته إدخال الطعام إلى المعدة من الفم، و هو هنا استعارة للأخذ بقصد الانتفاع دون إرجاع؛ لأن ذلأك الأخذ يشبه الأكل من جميع جهاتها.

ونسب الأمو ال إلى المخاطب في قوله: (أمو الكم)؛ للزيادة في التنفير من هذا الفعل؛ وللتأثثر في المخاطب، وكأنه يستثير فيه

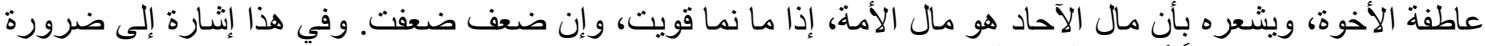
التعاون بين الناس بدل النًَّالم في أكل الأموال.

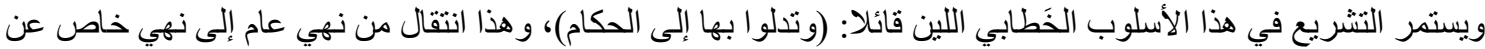
قضية الرشوة و إعطاء المال لأهل السلطان، أو استعمال الجاه لأكل أمو ال الناس.

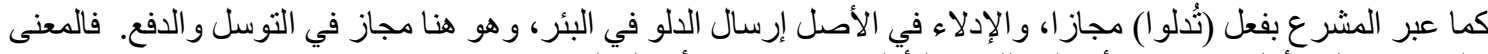

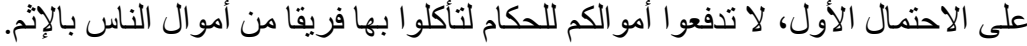

و الإدلاء بها هو دفعها لإرشاء الحكام ليقضو اللدافع بمال غيره، فهي تحريم للرشوة، وللقضاء بغير الحق، و لأكل المقضي له

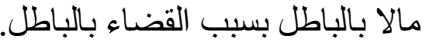

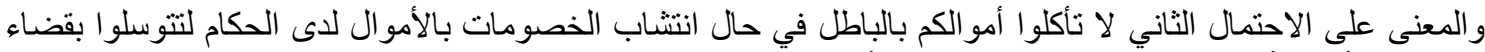
الحكام إلى أكل الأمو ال بالباطل حين لا تسنطيعون أكلها بالغلبه التئ.

و الملاحظ استعمال أسلوب لين، رغم أن المقام مقام نهي عن فعل قبيح يتعلق بأكل أمو ال الناس بالباطل؛ لأن الفئة المخاطبة

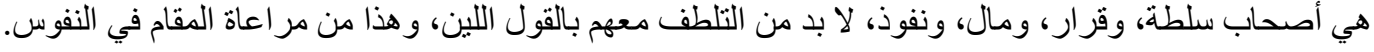

وختم هذا النص باستعمال أسلو ب الإطناب؛ عند قوله تعالى: (و أنتم تعلمون)، حيث جاءت الجملة لتأكيد وتشنيع الفعل المرتكب. فقول المشرع: (و أنتم تعلمون) حال مؤكدة؛ لأن المدلي بالأمو ال للحكام ليأكل أمو ال الناس عالم لا محالة بصنعها، فالمر اد من هذه الحال تثنيع الأمر وتفظيعه9.

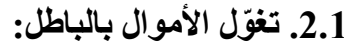

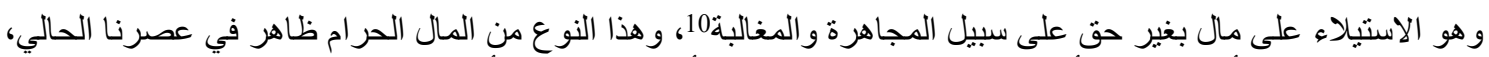

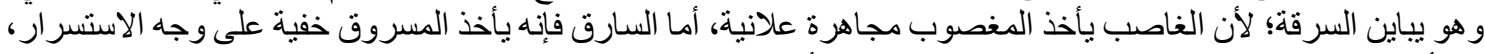

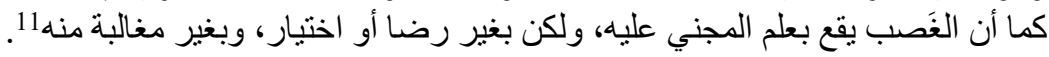

وحكم السارق يباين حكم الغاصب، إذ لا قطع عليه على رأي أغلب الفقهاء12. ويلزم الغاصب أن برد المغصوب لصاحبه.

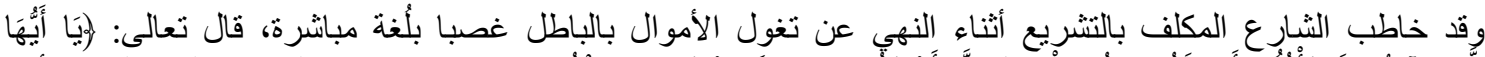

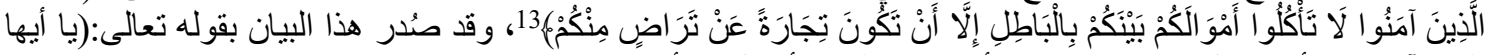

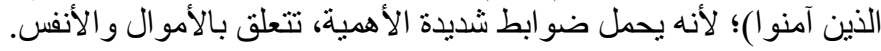

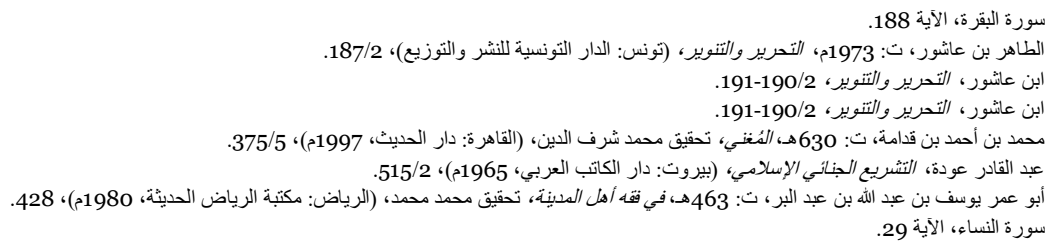




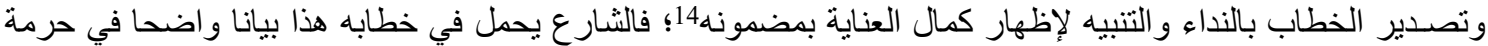

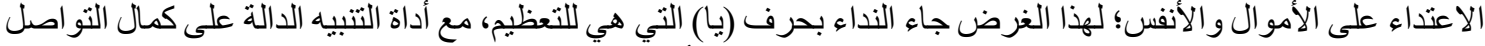
بين المشرع و المخاطب في الحالات التي تنطلب استجابة فورية للأو امر وألنو اهي. لأني.

و هذه طريقة خاصة في الإقناع. فعندما يريد المشرع أن يدعو المخاطبين إلى أن يؤمنو ا به يلفتهم إلى الكون، ويلفتهم إلى ما

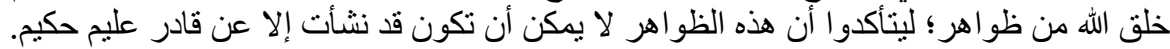

و إذا ما انتهوا إلى الإيمان به استقبلو ا التكليف الذي يتمثل في افعل كذا ولا تفعل كذا.

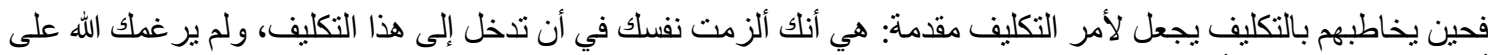

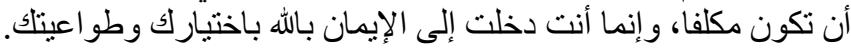

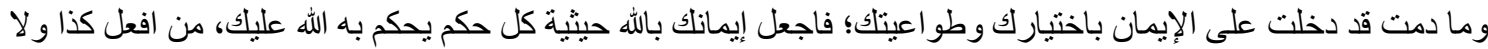

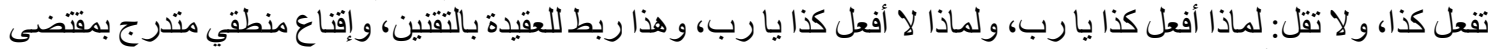

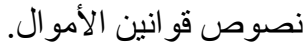

كما أطلق المشرع لفظ (الأكل) على تعدي الأمو ال، و هو مجاز في الانتفاع بالثيء انتفاعا تاما، لا يعود معاه إلى الغير. فأكل

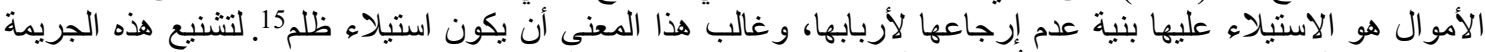

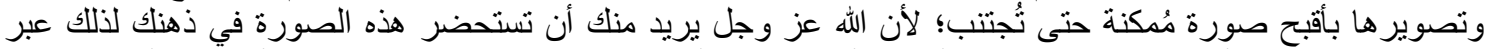

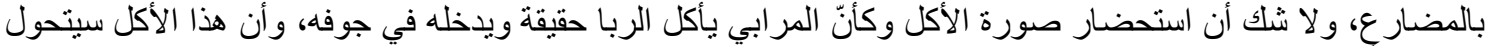

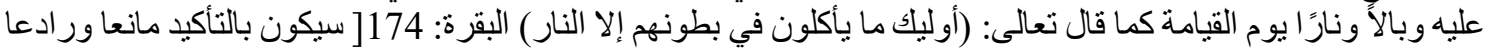
لكل من تسول له نفسه اقتر اف هذه الجريمة فالفئ.

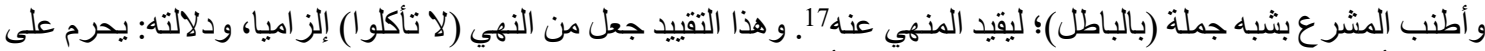
بعضكم أكل مال البعض، كما يحرم على المؤمن قتل أخيه المؤمن.

و إنما قدم النهي عن الأموال؛ لأن المقام مقام حديث عن الأمو ال والتجارة، و لاستسهال المجتمع العربي الجاهلي يومئذ أكل

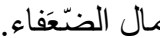

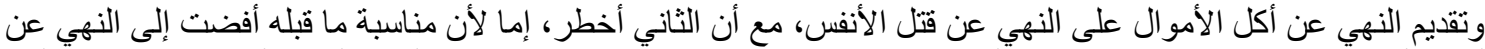

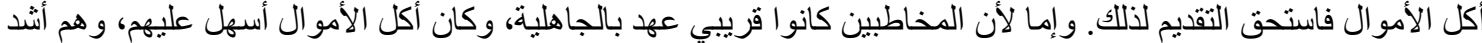
استخفافا به منهم بقتل الأنفس.

ولأن المال كان يقع في مواقع الضعف؛ حيث لا يدفع صاحبه عن نفسه كاليتيم والمرأة فآكل أموال هؤلاء في مأمن من التبعات بخلاف قتل النفس، فإن تبعاته لا بسلم منها أحد 18.

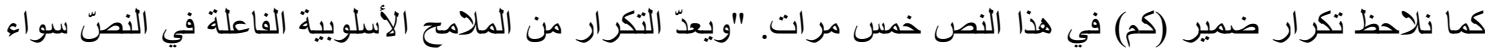

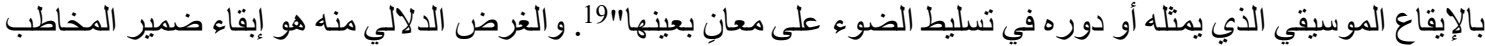

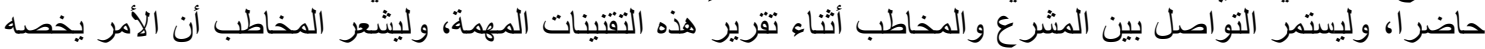

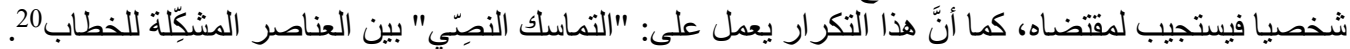

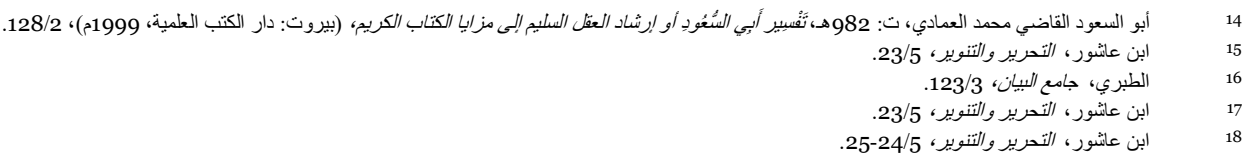

19 M. H. M. Abdul Qader, "el-Farazdaq’’n yeğeni için ağıtı: Analitik ve biçimsel bir çalışma”. RumeliDE Dil ve Edebiyat Araştırmaları Dergisi, 22 (2021):766-781, 775. 
كما عبر المشرع بحرف (عن) مجاز ا في قوله تعالى: (تجارة عن تراض مناض منكم) ، فحرف (عن (عن) فيه للمجاوزة، و المعنى:

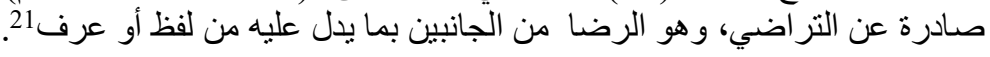

وكان من الممكن التعبير ب (اللام) للتعليل هنا؛ لأنها تفي بالمعنى، لكن حرف (عن) يحدد الدلالة الدقيقة لرضا الأطر اف. فحرف (عن) أفاد السببية أو التعليل، ولذا فالتجارة الناتجة عن تر اض استثنيت من الأكل الباطل22. ويساعد الوقوف عند هذا التعبير الحسم في حكم فقهي خلافي: هو تمام البيع بتر اضي الطرفين في مجلس واحد.23. و واعتبر الطاهر بن عاثنور هذا التعبير مستندا لقول ماللك من نفي خيار المجلس؛ لأن الله جعل مناط الانعقاد هو التراضي، و التز اضي يحصل عند التبايع بالإيجاب و القبول24.

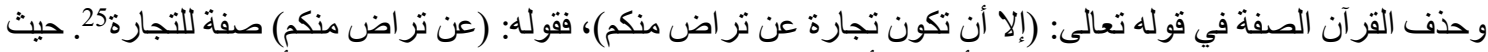

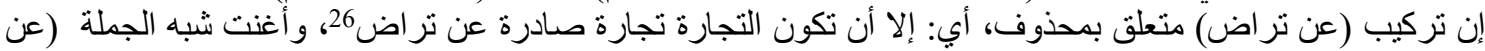
تر اض) عن الصفة المحذوفة.

$$
\text { و الغرض من هذا إيجاز الكلام؛ لالالة السياق عليه؛ وعدم الخوف من ضياع المعنى التام المحكم. }
$$

2

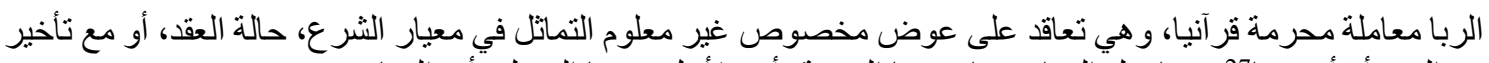

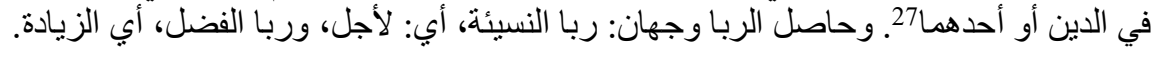

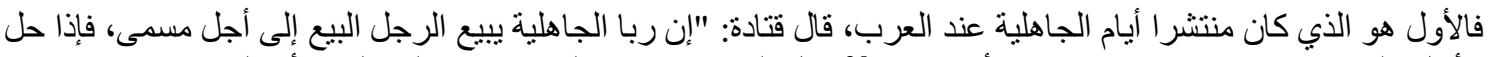

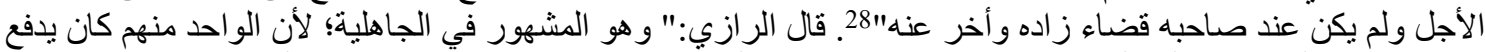

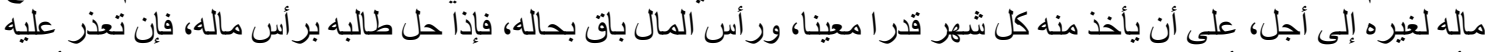

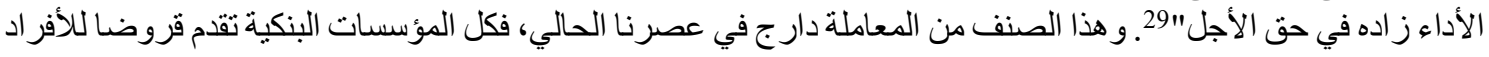

\footnotetext{
ابن عاشور، التحربير والتنتوير، 24/5-25.

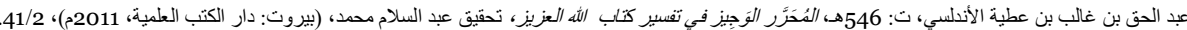

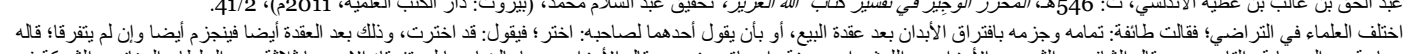

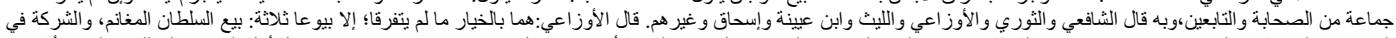

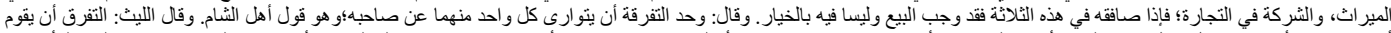

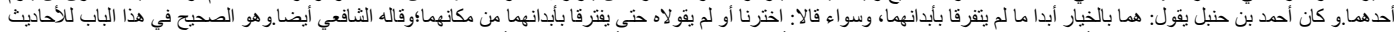

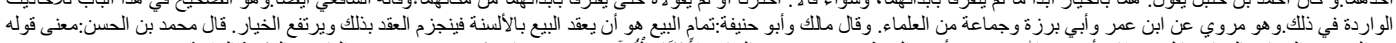

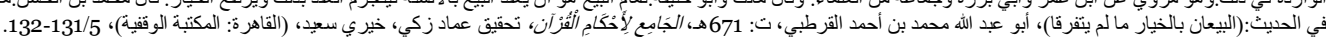

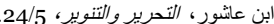

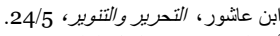

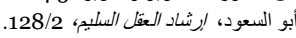

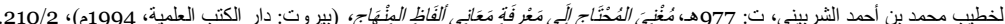

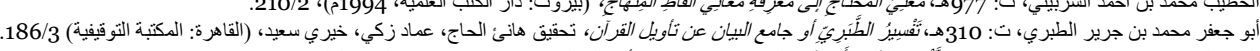

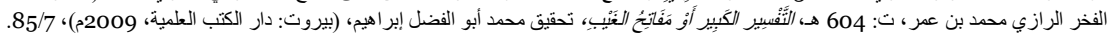


و المؤسسات مقابل زيادة ثابتة، وترتبط الزيادة بحاصل ضرب هذه النسبة بأصل القرض و عدد أثنهر السداد، فكلما زاد أجل السداد زاد المبلغ المترتب على هذه النسبة وترنبة

و الثناني هو ربا الفضل، وهو الذي يكون في عملة واحدة، مثل بيع الدينار بالدينارين، أو ثلاث غر امات من الذهب بأكثر منها. فالمشرع حرم هذه المعاملات تحريما شديدا، حيث تدرج في التحريم، بشكل متسلسل.

1.2. تصوير أولي لمعاملة الربا:

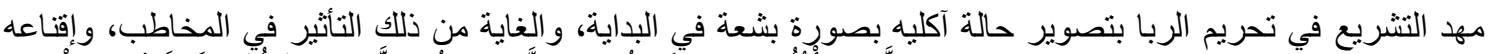

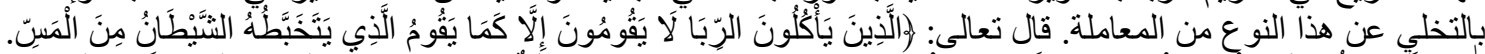

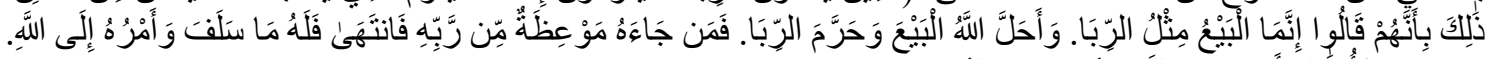

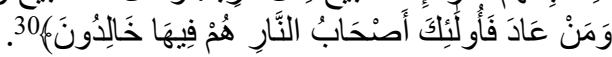

حيث عبر عن التعامل بالربا بقوله: (بأكلون)، وهي استعارة؛ لأن الأكل أعظم منافع المال، يقول البغوي: (والذين يأكلون

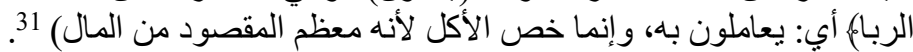

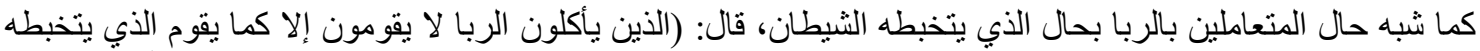

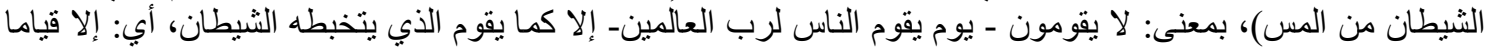
كقيام الذي يتخبطه الثيطان.

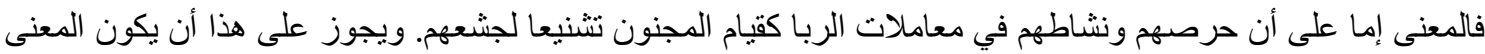

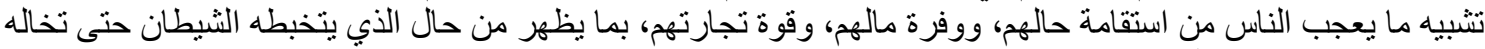

قويا سريع الحركة، مع أنّه لا يملك لنفسه شيبئامن.

فالغرض الأساس من أسلوب التتبيه هنا هو : تبشيع صورة المتعامل بالربا. وهو تصوير حكيم لعملية الربا؛ لأن العلاقة بين هذه العطلية والذي يتخبطه الثبطان علاقة منقاربة.

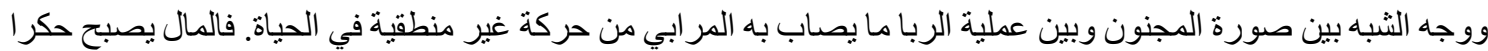

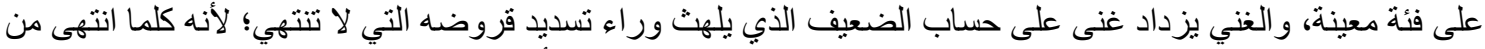

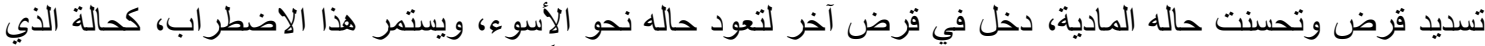
يتخبطه الثنيطان من المس. و هي إثارة إلى بعض الاضطر ابات العصبية و النَّسية التي تفقد الجسد توازنه ونظامه العام في لإني

هذا إذا ربطنا التشبيه بحال المر ابي في الدنيا، أما إذا اعتبرنا التثبيه خاصا بيوم القيامة، فيكون المعنى: لا يقوم حقيقة في

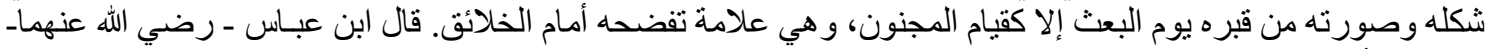

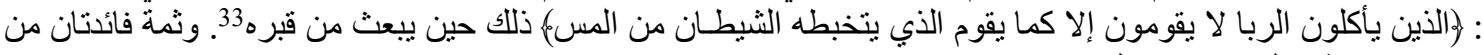

مجيء (تخبّط) على وزن (تفعلّ):

الأولى: أن التخبّط مطاوع خبطه، ومعنى المطاو عة هنا قبول الأثر و التأثير، نحو: قطعت الثوب فانقطع الثوبُ، فالمطاوع في الحقيقة هو الثوب؛ لأنه قبل الأثر من الفاعل وطاو عهد3.

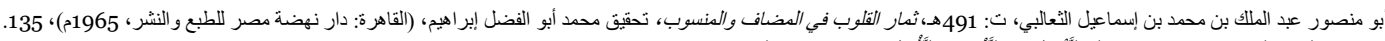

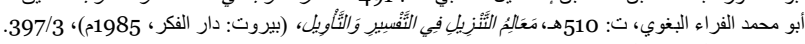
ابن عاثور ، التحريز والتنوبير،

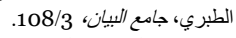
ابن عاشور ، التحربير والتنوير، 1089/2. 
الثانية: بمعنى التكلف، أي تكلف الثيطان خبطه، وأر اد أن يحصل فيه حقيقة، واجتهد في زيادة هذا الخبط فيه، وشق به عليه،

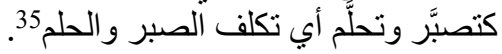
وفي تعلّق (من المس) وجهان:

الأول: أنه متعلق بـ(لا يقومون)، و(من) ابتدائية، أب تخبطا مبندأ من المس، و التقدير: لا يقومون من المس الذي لهم إلا كما

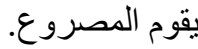

الثاني: أنه متعلق بقوله (يقوم). و التقدير: لا يقومون إلا كما يقوم المتخبط بسبب المس36. (5).

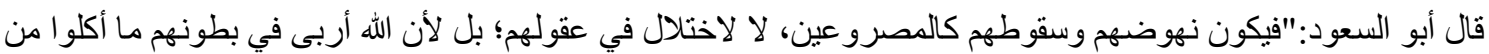

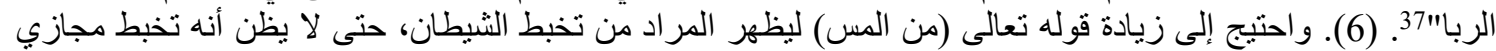

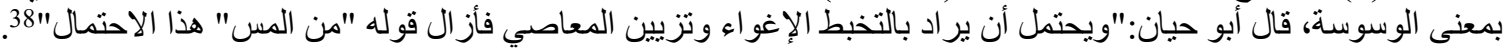

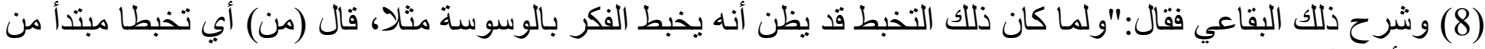

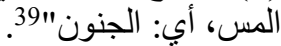

واستعمل المشرع اسم الإشارة (ذلك) في قوله: (ذللك بأنهم قالو ا إنما البيع مثل الربا) إيجاز ا في الكلام، وهو عائد إلى الصورة البشعة التي صورت آنفا: اضطر الاب حالّهم في الدنيا، وقيامهم من الأجداث كقيام المجنون.

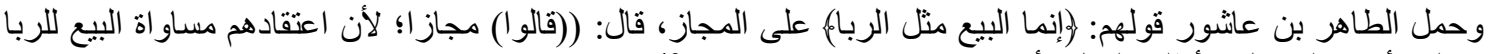

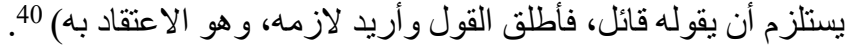

فالتعامل بالربا تَرسَّخ في اعتقادهم حتى صـار أصلا، ولهذا جاء المشر ع بالتشبيه المعكوس مبالغة؛ ليصور حالهم واعتقادهم،

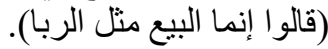

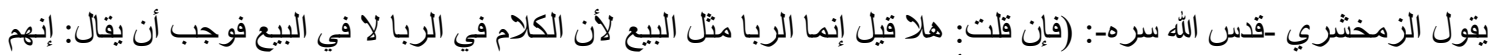

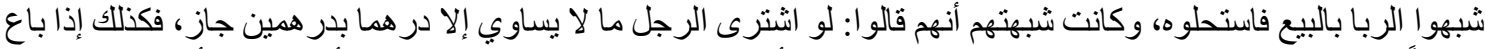

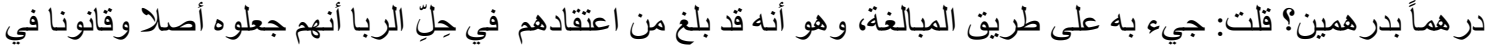

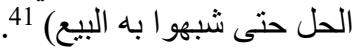

ولهذا أيضا استعمل المشرع أسلوب القصر هنا في قوله: (إنما البيع مثل الربام). ومعلوم أن القصر بـ (إنما) يستخدم في الأمر

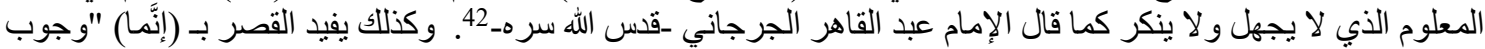

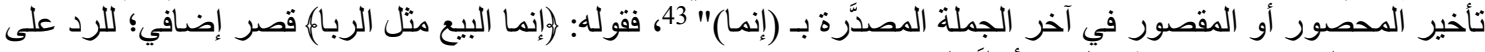
من ز زعم تخالف حكمهما، فحرَّم الَربا وأحلَّ البيع.

ورد ابن عاثور صورة التشبيه المعكوس في هذه الجملة فقال: ولما صُر ح فيه بلفظ مثل ساغ أن أنقال التقال البيع مثل الربا كما

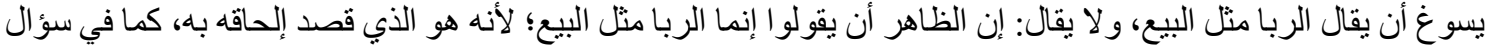


وبنى عليه جعل الكلام من قبيل المبالغة؛؛ لأنا نقول: ليسوا هم بصدد إلحاق الفروع بالأصول على طريقة القياس، بل هم كانو ا الإسبا

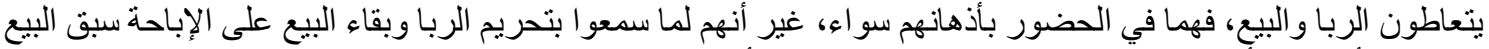

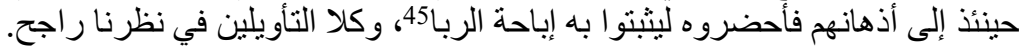

$$
\text { ثم عاد القرآن في النهاية ليثبت حلية البيع وحرمة الربا، قال: (وأحل الله البيع وحرم الربا). }
$$

ومن الملاحظ ذكر الفاعل (الله) عند ذكر البيع، وإضماره عند ذكر الربا. والغاية الثَّايَّةَّة وراء ذلك: التفريق بين المعاملتين،

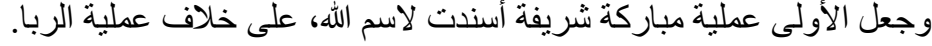

واختتم الثشارع هذا التمهيد بقوله: (فمن جاءه مو عظة من ربه فانتهى فله ماسلف)، وهذ وذا إيجاز تقدير ضم معاني كثيرة، أي: من انتهى عن هذه العطلية غفرت خطاياه، وجعلت لله لا عليه، و لا يحاسب عن عن ما مضى من معاملات.

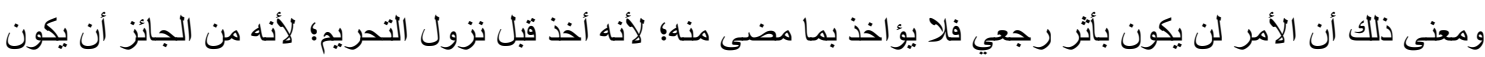

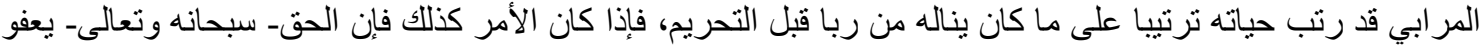

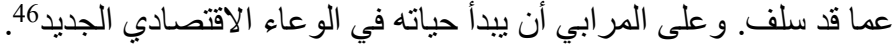

و الغاية الدلالية من هذا تحفيز المخاطب بترك التعامل بالربا؛ لأجل بناء معاملاته المالية بشكل سوي.

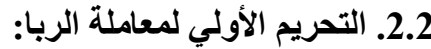

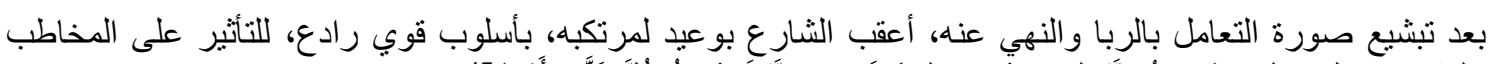

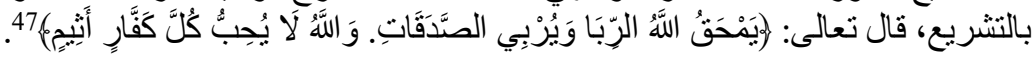

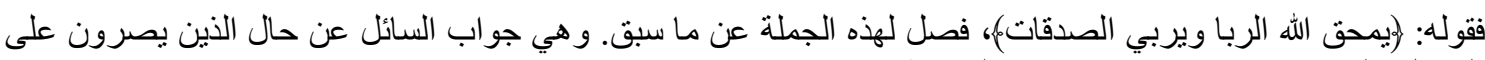
التعامل بالربا، و لا ينتهون بعدما جاءتهم المو عظة.

واختار المشرع لفظا قويا (يمحق)، للالالة على كمال الإذهاب و الإز الة بالكلية بقوة وسطوة. و المعنى: محو البركة من مال

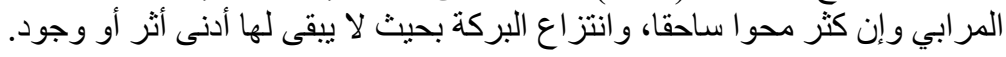

وحذف القرآن جملتي: (يعاقب عليه) و (يباركه) في هذا النص؛ لأن السياق يدل على هذا. و ولأنه لما جعل المحق بالربا، وبا، وجعل

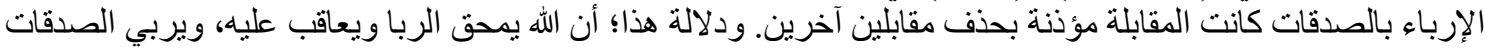

ويبارك لصاحبهاء بالصنات

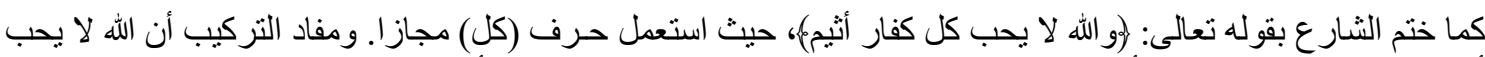

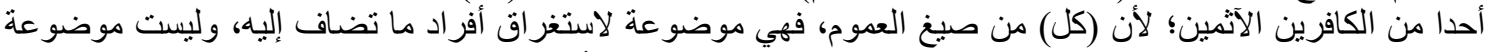

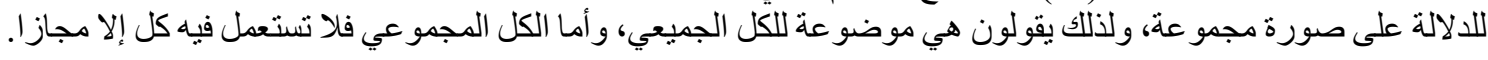

$$
\text { فإذا أضيفت (كل) إلى اسم استغرقت جميع أفر اده، سو اء ذلك في الإثبات وفي النفي } 49 .
$$

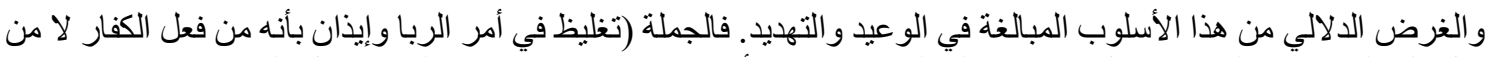

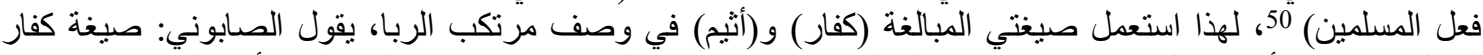

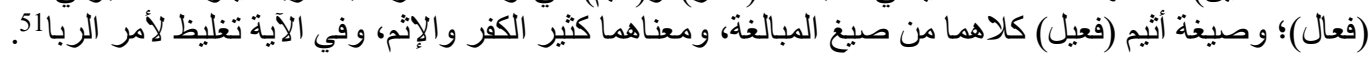

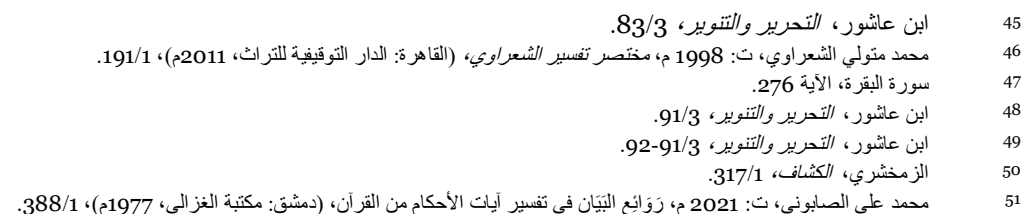




\section{3. - 2.3 التحريم القطعي لمعاملة الربا:}

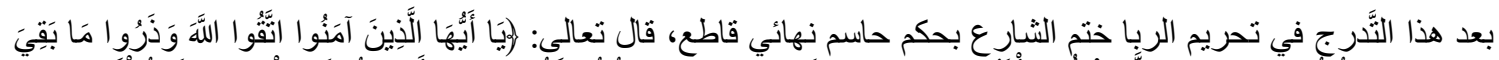

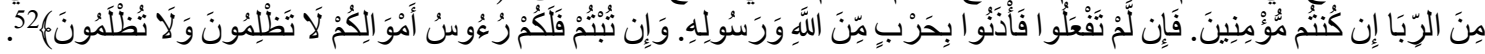

فالملاحظ تصدير هذا الحكم بعبارة الاستهلال (يا أيها الذين آمنوا)، وهذه العبارة مقدمة للنصوص القدان القانونية القرآنية الحاسمة.

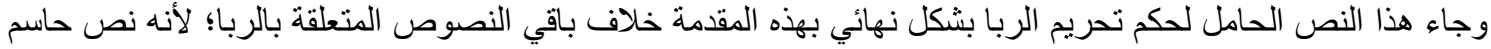
في التحريم.

فالثار ع بعدما قدم بالنصوص السابقة التي صور فيها الربا بأبشع الصور ، أتى إلى مرحلة الحسم، و هذه عادة التشريع القراني التي تأتي بالتدرج في تحريم عادة درج عليها المجتمع.

فقوله: لويا أيها الذين آمنوا اتقوا الله وذروا ما بقي من الربام) إفضاء إلى التشريع بعد أن قدم أمامه من الموعظة ما هيأ النفوس إليه43.

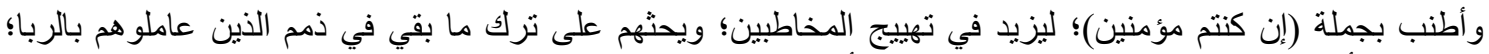

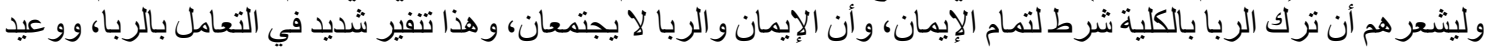
رهيب لمن يصر على التعامل به.

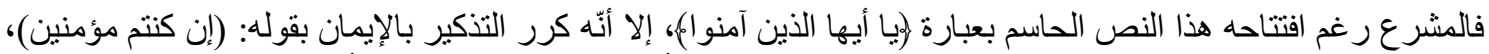

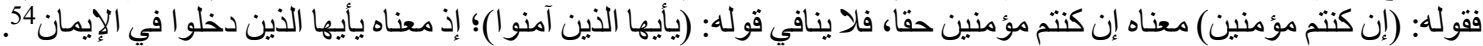
فالغرض منه زيادة التأكبد.

و هذا أسلوب إقناعي، أي: إن آمنتم على الحقيقة فإن ذلك مستلزم لامتثال ما أمرنم به البتة. وهو شرط حذف جو ابه ثقة بما

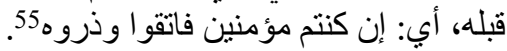

و التعامل بالربا لا يذهب بأصل الإيمان كما قال الزمخشري و المعتزلة

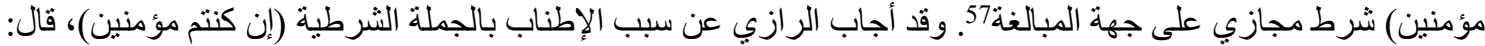
فإن قيل: كيف قال: (يا أيها الذين آمنوا اتقو ا) ثم قال في آخره (إن كنتم مؤمنِين).

الجو اب من وجوه: الأول: أن هذا مِثل ما يقال: إن كنت أخا فأكرمني، معناه: إن من كان أخا أكرم أخاه، و الثناني: قيل: معناه إناه

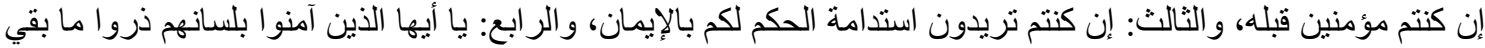

وهذا كله حجاج للمخاطب، ومحاولة لإقناعه و إلز امه بحكم تحريم الربا.

وبعد هذا الأسلوب الإقناعي، تحوَّلَ التشريع إلى أسلوب زجري في نبرة تهديد وو عيد، قال تعالى:زفإن لم تفعلو ا فأننو ابحرب من الله ورسولدم).

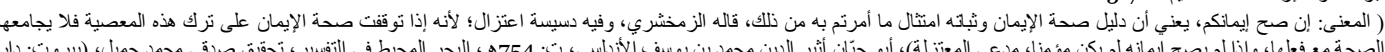

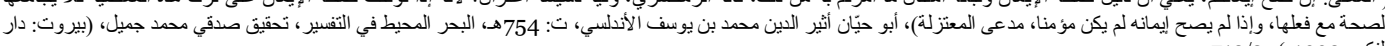


(وتنكير الحرب لقصد تعظيم أمر ها) 59 ، أي: حرب عامة لا يحيط بها وصف، وفي هذا تهويل، وتعظيم، وتفخيم. يقول أبو السعود: (وتنكير حرب اللتفخيم)

و والحرب هنا ليست على وجه الحقيقة كما فهم البعض61، بل خرجت مخرج التهويل، فلا حرب حقيقة وإنما هو تهايد وتخويف62.

$$
\text { ولزيادة التهويل والتخويف أسندت الحرب إلى الله ورسوله، فتنكير (حرب) لقصد تعظيم أمر ها. }
$$

ولأجل هذا المقصد عدل عن إضافة الحرب إلى الله، وجيء عوضا عنها بمن ونسبت إلى الله؛ لأنها بإذنه على سبيل مجاز الإسناد، و إلى رسوله لصلى الله عليه وسلم- لأنه المبلغ و المبانشر 63.

وبالإضافة إلى هذا المعنى الذي أثنار إليه ابن عانشور ، يمكن أن يكون حرف (من) متعلقا بمدذوف وقع صفة للحرب، لتأكيدها وتفخيمها، أي: بنوع من الحرب عظيم لا يقادَر قدره64.

و عدم ذكر نوع الحرب أبلغ لييقى المعنى عاما، فإن قلت: هلا قيل بحرب الله ورسوله؟ قلت: كان هذا أبلغ؛ لأن المعنى: فأذنوا بنوع من الحرب عظيم عند الله ورسوله صلي صلى الله عليه وسلم فلمان.

وبعد هذا الأسلوب القوي، ختم النص بأسلوب لين، قال تعالى: (وفإن تنتم فلكم رؤوس أموالكم)، وتسمية أصل المال رأسا مجاز 66. كما اختار المشرع هذا اللفظ ليخبر المخاطب أن ما بقي من المال فيه بركة، وليقتنع أخير ا بترك ما بقي من الرِّبا. 3. القِمَار:

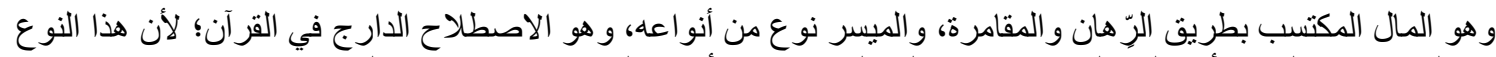

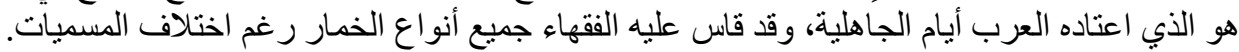

و المقصد من تحريمه ما يوقع في النفوس من شحناء وبغضاء، قال ابن تيمية: "أخبر سبحانه أن الميسر يوقع العداوة و البغضاء

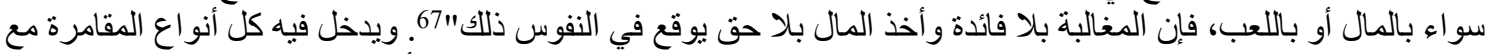

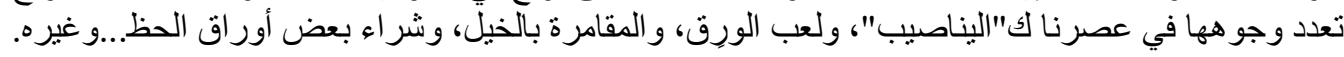

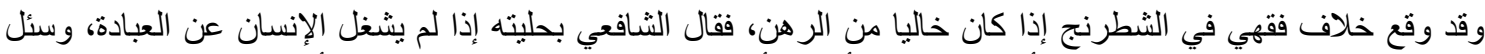

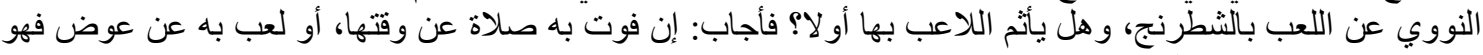

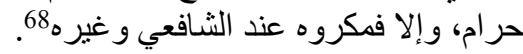

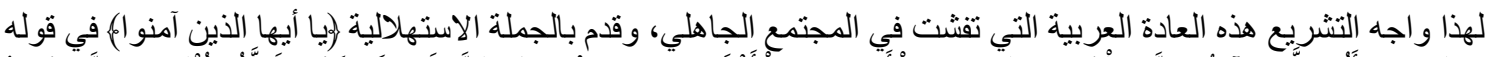

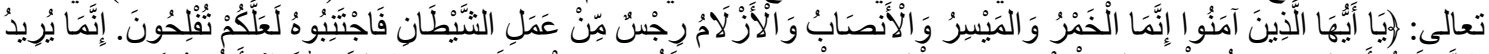

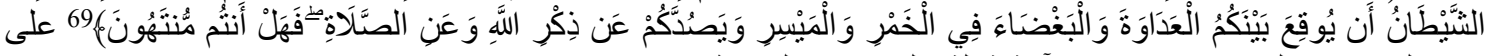

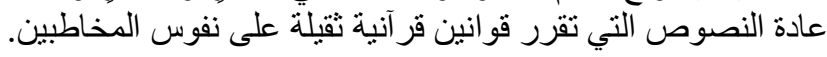

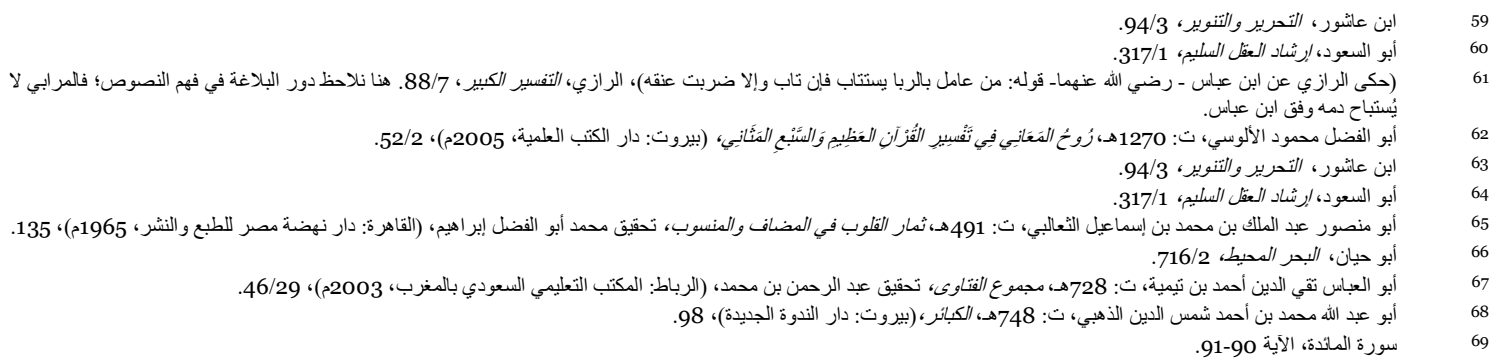


فالغرض من هذه المقدمة الإقناع، واستجاثة قلوب المؤمنين من جهة، وتذكير هم بمقتضى هذا الإيمان من الالتز ام والطاعة

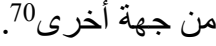

بعد ذللك حصر المنهيات وقصر عليها (الرجس) في قوله تعالى: (إنما الخمر والميسر والأنصاب و الأزلام رجس من عمل الثيطان) (11).

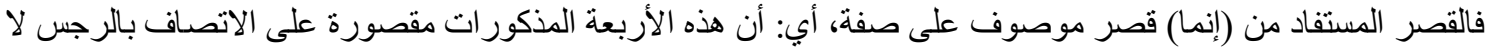

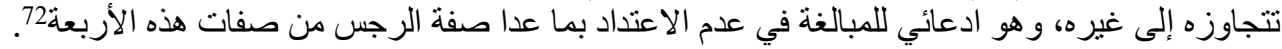

$$
\text { فالمقصور : الخمر + الميسر + الأنصاب + الأزلام. }
$$

و الغاية الثاوية ور اء هذا القصر: أن بعض أفراد المجتمع الجاهلي اعتاد شرب الخمر، والقِمَار، و الاستقسام بالأز لام و عبادة الأصنام.

و العادة لما تَتَوَغَّل في النفوس يصعب تغيير ها دفعة واحدة، لهذا عمد التقنين القر آني إلى تبشيع هذه المعاملات، وقصر الثر عليها رغم أنه ذكر في نص في آخر أن للخمر منافع، لكنه هنا جعله رجسا لغا لغان غير.

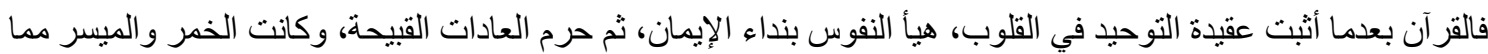

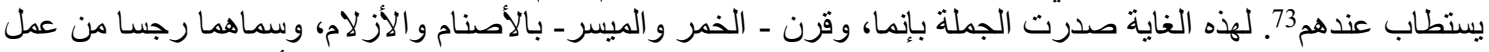

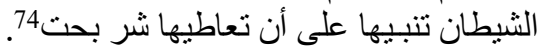

بعد ذلك خص الخمر والميسر؛ ليعلم المخاطب أن النص جاء لأجل تحريم الخمر والقمار أصالة.

ولأن الخطاب موجه للمؤمنين، فمن المسلمات تخليهم عن الأصنام، لذا جمع المشرع الخمر و الميسر مع الأنصاب والأزلام

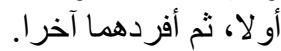

فالخطاب مع المؤمنين، و إنما نهاهم عما كانو ا يتعاطونه من شرب الخمر و اللعب و الميسر، وذكر الأنصاب و الأز لام لتأكيد

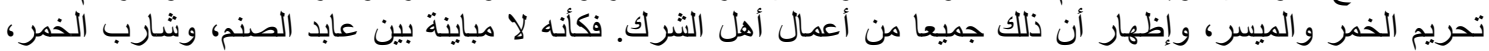
و المقامر.

ثم أفردهما بالذكر ، لبعلم أنهما المقصود بالذكر 75.

ولتاكيد النهي قال تعالى بصيغة الأمر: (فاجتنبوه)؛ ليشدد على أن الأمر للوجوب. وحشد المشرع هذه المؤكدات كلها؛ ليكون النص دليلا حاسما في تحريم الخمر و القمار.

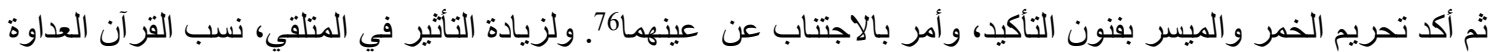
و البغضاء للخمر والميسر مستعملا حرف (في) عن طريق المجاز العقلي، قال تعالى: زيريد الثيد الثنيطان أن يوقع بينكم العداوة في الخمر والميسر). فحرف (في) من قوله: (في الخمر و الميسر)؛ للسبيبة أو الظرفية المجازية، أي: في مجالس تعاطيهما77. 
واختتم القر آن هذا النص بجملة تو اصل بين الثار ع و المخاطب، قال تعالى: (ففهل أنتم منتهون). حيث جاء بالاستفهام؛ لتمثيل حال المخاطبين بحال من بين له المتكلم حقيقة شيء؛ ثم اختبر مقدار تأثيثر ذللك البيان في نفسه، وفي هذا الاستفهام من بديع لطف الخطاب ما بلغ به حد الإعجاز 78.

و الاستفهام هنا لبس اختياريا بل يحمل معنى الزجر وثبوت ما سبق تحريمه، لهذا جعلت الجملة بعد (هل) اسمية؛ لدلالتها على ثبات الخبر ؛ وزيادة في تحقيق حصول المستفهم عنهولئ.

وصيغة التقنين و إن جاءت في النص بأسلوب الاستقهام في الظاهر إلا أن المر اد منه هو النهي في الحقبقة. و إنما حسن هذا الإنا المجاز ؛ لأنه تعالى ذم هذه الأفعال و أظهر قبحها للمخاطب، فلما استفهم بعد ذللك عن تركها لم يقدر المخاطب إلا لأ على الإقرار

بالترك.

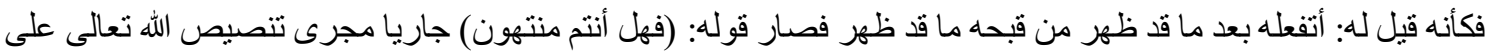

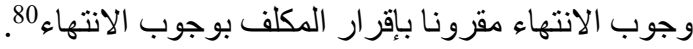

الخاتمة

نخرج من مدارستتا الدلالية البيانية التحليلية لنصوص المال الحرام في القرآن بجملة من النتائج:

- وضع الثارع قاعدة عامة في اكتساب الأموال، وهي الوضوح ومحاربة الغش و التحايل، وظلم القوي الضعيف،

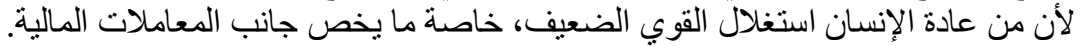

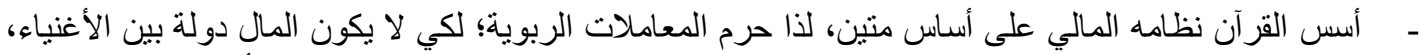

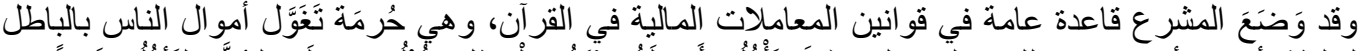

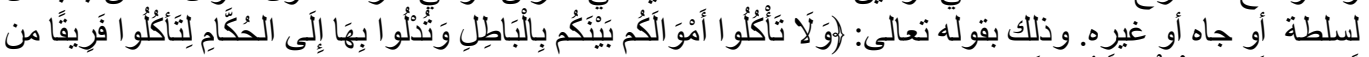

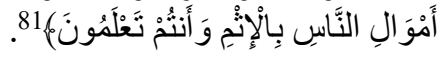

- و لإبلاغ هذه المعاني توسل الثارع بأساليب البيان؛ لتصوير المعاملات المالية المحرمة، ولتقرير نظامه الخاص.

- - - أسس الثار ع نصوصده وفق تركيب دلالي دقيق يخدم المقاصد الكبرى؛ لنظام الأمو ال في القرآن الكريم.

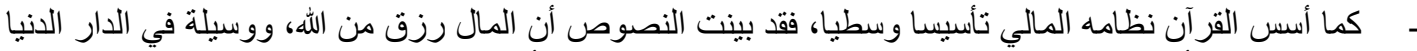

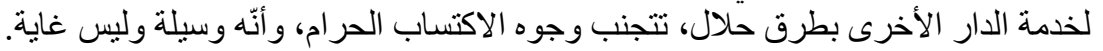

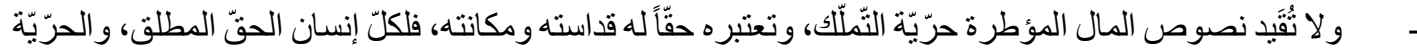

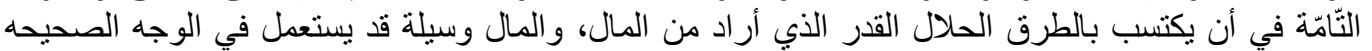

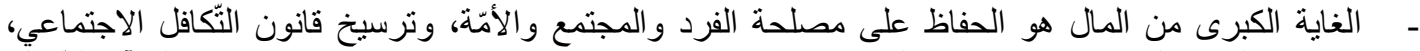

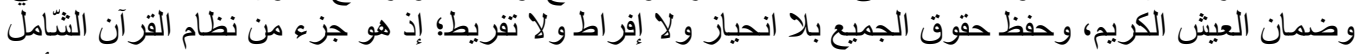

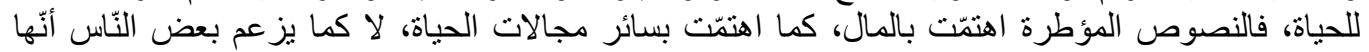

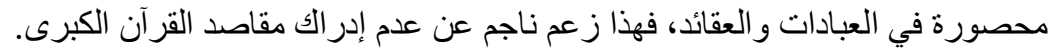




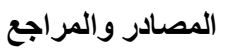

\section{Kaynakça}

Abdul Qader, M. H. M. (2021). "el-Farazdaq’ın yeğeni için ağıtı: Analitik ve biçimsel bir çalışma". RumeliDE Dil ve Edebiyat Araştırmaları Dergisi, (22), 766-781. DOI: 10.29000/rumelide.897384

Anîs, İbrahîm. (1965). Mûsîqâ eş-şi rr. 3. Basım. Kahire: Mațabat'ül-Anglo el-Misriyyah.

Âlûsî, Ebû'l-Fadl Mahmûd. (2005). Rûhu'l-meânî fî tefsiri'l-Kur'âni'l-azîm ve’s-seb'i'l-mesânî, 2.bs., Beyrut, Dâru'l-Kutubi'l-'İlmiyye.

Begavî, Ebû Muhammed El-Ferrâ'. (1985). Meâlimu’t-tenzîl fi't-tefsîr ve’t-te’vîl, Beyrut, Dâru'l-Fikr, 1985 .

İbn Teymiyye, Ahmed, Mecmû'u'l-fetâvâ, er-Ribâd, el-Mektebu't-Ta'lîmiyyu's-Su'ûdî bi'l-Mağrib.

İbn Hazm, Ali b. Ahmed, el-Muhallâ, Thk: Lecnetu İhyâi't-Turâs, Beyrut, Dâru'l-Âfâkı'l-Cedîde.

Ebû Hayyân, Muhammed b. Yûsuf, (1992). el-Bahru'l-muhît fi't-tefsîr, Beyrut, Dâru'l-Fikr.

Hatîp Şirbînî, Muhammed b. Ahmed, (1994). Muğni’l-muhtâc ilâ ma'rifeti meânî elfâzi'l-Minhâc, Beyrut, Dâru'l-Kutubi'l-'ilmiyye.

Zehebî, Şemsüddîn, el-Kebâir, Beyrut, Dâru'n-Nedveti'l-Cedîdeti.

er-Râzî, Fahrüddîn Muhammed. (2009). et-Tefsîru'l-kebîr ev Mefâtîhu'l-gayb, 3. bs., Beyrut, Dâru'lKutubi'l-'İlmiyye.

Zemahşerî, Ebû’l-Kâsım Mahmûd. (2009). el- el-Keşşāf an ḥakāikı ġavāmiḍı"t-tenzīl ve uyūni"l-ekāvīl fi vucūhi"t-te"vill, 5.bs., Beyrut, Dâru'l-Kutubi'l-'İlmiyye.

Ebussuûd, Kadı Muhammed İmâdî, (1965). Tefsîru ebi's-Suûd İrşâdu'l-akli’s-selîm ilâ mezâya'kitâbi'l-kerîm, Beyrut, Dâru'l-Kutubi'l-'İlmiyye, 1999.

Kutub, Seyyid. (2004). Fî Zulâli'l-Kur'ân, 34.bs., Kahire, Dâru'ş-Şurûk.

Sâbûnî, Muhammed Alî, (1977). Ravâiu’l-beyân, 2.bs, Dımeşk.

Soliman, Abdelkarim Amin Mohamed, Savaş Ayetlerinin Meani İlmi Açısından İhtiva Ettiği Konular: Belağata Dair Bir İnceleme, Mîzânü'l-Hak: İslam İliami İlimler Dergisi 10(Haziran 2020): 137186.

Soliman, Abdelkarim Amin Mohamed, Savaş Ayetlerinde Tekrar Üslup Açısından Bir İnceleme, Bayburt Üniversitesi İlahiyat Fakültesi Dergisi, 11 (Yaz) 2020) : 129-161

Taberî, Ebû Ca'fer Muhammed, Tefsîru’t-Taberî, Thk: Hânî el-Hac, İmâd Zekî ve Hayrî Saîd, Mısır, elMektebetü't-Tevfikiyye.

İbn Âşûr, Muhammed Tâhir, et-Tahrîr ve't-Tenvîr, ed-Dâru't-Tûnisiyye li’n-Neşri ve't-Tevzî.‘

İbn Abdi'l-Barr, Ebû Ömer, (1980). Fî fikh-i ehli'l-Medîne, Thk: Muhammed Muhammed, 2.bs., erRiyâz, Mektebetu'r-Riyâzi'l-Hadîse.

İbn Atiyye, Kadı ebû Muhammed, (2011). el-Muharraru'l- vecîz, Thk: Abdü's-Selâmi Muhammed, Beyrut, Dâru'l-Kutubi'l-'̇lmiyye.

Ûdeh, Abdülkâdir, et-Teşrîu'l-cinâinyyü'l-İslâmî, Beyrut, Dâru'l-Kutubi'l-Arabî.

Feyyûmî, Ahmed b. Muhammed, el-Misbâhu'l-münîr, Mektebetu Lübnân.

Şevkânî, Muhammed b. Alî, (1993). Fethu'l-kadîr, Thk: Seyyid İbrâhîm, Kahire, Dâru'l-Hadîs.

İbn Kudâme, Ahmed b. Muhammed, (1997). el-Muğnî, Thk: Muhammed Şerefu'd-Dîn, Kahire, Dâru'lHadî.

Kurtubî, Ebû Abdillâh Muhammed, el-Câmi“ li-ahkâmi'l-Kur'ân, Thk: İmâd Zekî ve Hayrî Saîd, elMektebetü'l-Vakfiyye. 
830 / RumeliDE Journal of Language and Literature Studies 2021.25 (December)

Texts of forbidden money in the Holy Qur'an: Graphic semantic approach / M. Kaddum; A. Alami (pp. 814-830)

Şa'râvî, Muhammed Mutevellî, (2011). Muhtasar tefsîri'ş-Şa'râvî, Kahire, ed-Dâru’t-Tevfikkiyye li’tTürâs.

Nesefî, Abdullâh b. Ahmed, (1989). Tefsîru'n-Nesefî, Beyrut, Dâru'l-Kalem. 